Article

\title{
'Damn It, I Am a Miserable Eastern European in the Eyes of the Administrator': EU Migrants' Experiences with (Transnational) Social Security
}

\author{
Elisabeth Scheibelhofer * and Clara Holzinger \\ Department of Sociology, University of Vienna, 1090 Vienna, Austria; E-Mails: elisabeth.scheibelhofer@univie.ac.at (E.S), \\ clara.holzinger@univie.ac.at (C.H.) \\ * Corresponding author
}

Submitted: 15 March 2018 | Accepted: 30 March 2018 | Published: 30 August 2018

\begin{abstract}
The European Union has given itself unique worldwide regulations so that EU citizens can port their social rights transnationally in case of migration. Yet this political and legal statement becomes flawed once a sociological perspective is adopted to look into the actual experiences of migrants. TRANSWEL (2015-2018), an ongoing international research project-applying a mixed-method approach to compare four country-pairs (Bulgaria-Germany, Estonia-Sweden, HungaryAustria, Poland-UK)-has shown that mobile EU citizens are confronted with exclusion and discrimination and that their belonging is put into question. Based on qualitative interviews with migrants, we argue that welfare institutions in the 'old' EU member states (partially) exclude and potentially discriminate against mobile EU citizens. Exclusion and discrimination are mainly based on two types of experiences: First, the difficulty to navigate through a complex system of (transnational) regulations and administrative structures, and second, the burden to prove that one falls into the competency of the member state in question. The article points out that the EU-commonly referred to as the global best-practice example in terms of the portability of social rights-reveals its flaws and limitations once the actual experiences of migrants are scrutinized in this multilevel system of governance.
\end{abstract}

\section{Keywords}

European Union; migration; qualitative interviews; social security; transnationalism

\section{Issue}

This article is part of the issue "Migration, Boundaries and Differentiated Citizenship", edited by Terry Wotherspoon (University of Saskatchewan, Canada).

(C) 2018 by the authors; licensee Cogitatio (Lisbon, Portugal). This article is licensed under a Creative Commons Attribution 4.0 International License (CC BY).

\section{Introduction}

Managing social security in the event of migration and international mobility is becoming a key concern in the global discussion surrounding migration (Avato, Koettl, \& Sabates-Wheeler, 2010; Sabates-Wheeler, Koettl, \& Avato, 2011; Sabates-Wheeler \& Koettl, 2010). In this debate, social researchers and legal scholars together agree that the EU has come up with a unique transnational regulatory system that allows intra-EU migrants to port their social rights from one member state to another under certain conditions. These conditions have been subject to fierce political and scholarly debates (Ehata \& Seeleib-
Kaiser, 2017; Favell, 2016; Kymlicka, 2015). The legal framework fostering social security for EU citizens itself is a complex issue which is not only based on regulations EC $883 / 2004$ and EC $987 / 2009$, but also changing over time with different court rulings on the issue (Blauberger \& Schmidt, 2014; Carmel, Cerami, \& Papadopoulos, 2011; Heindlmaier \& Blauberger, 2017).

Regarding transnational social protection from such a legal angle, the EU is clearly the best-practice example world-wide when it comes to securing the social rights of migrants who are mobile in a number of countries (Dobbs \& Levitt, 2017; Faist, 2017; Faist, Bilecen, Barglowski, \& Sienkiewicz, 2015; Levitt, Viterna, Mueller, 
\& Lloyd, 2017). Yet what has been less thoroughly focused on until very recently is whether the political goal of EU citizens' non-discrimination is actually a social reality represented by the experiences of those citizens themselves. In order to follow up on this research interest, an international team within the TRANSWEL project examined the social rights of mobile citizens in policy and practice by applying a mixed-method approach. The focus was in four areas, namely health insurance, unemployment benefits, retirement benefits, and familyrelated benefits.

\section{Methodology}

In the following, we present our comparative analyses based on the last phase of the TRANSWEL project, a Grounded Theory study that investigated how mobile EU citizens experience, organise, and manage their welfare transnationally. In total, 81 problem-centred qualitative interviews (Scheibelhofer, 2008; Witzel \& Reiter, 2012) with migrants from four different 'new' EU member states living and/or working in four different 'old' member states were carried out. Additionally, we conducted 22 interviews with their significant others-family or close friends-in the respective country of origin. The TRANSWEL project covered four country-pairs: BulgariaGermany (lead: Anna Amelina), Estonia-Sweden (lead: Ann Runfors), Hungary-Austria (lead: Elisabeth Scheibelhofer), and Poland-UK (lead: Emma Carmel). Countrypairs were studied due to prior findings regarding the importance of differences within welfare state regimes in terms of migration (Faist, 2017). With the last rounds of EU enlargements, migration from so-called 'new' member states to 'old' ones was deemed to be a research focus of particular importance with respect to transnational social protection. The 'old' countries of immigration were selected in order to contrast countries with strict labour market restrictions for EU migrants (Austria and Germany) and less restrictive countries in this regard (UK and Sweden) because we expected to find ensuing differences in the cross-border social security experiences of mobile EU citizens. On the other hand, the selection of 'new' countries of emigration aimed to compare sending countries with differing migration histories to the respective immigration countries (long-term: HungaryAustria and Poland-UK/ short-term: Bulgaria-Germany and Estonia-Sweden). The reason for this was the assumption that migration history influences the organisational structures of diasporic communities which in turn play an important role in the provision of relevant information concerning the access to social security rights.

Concerning the selection of interview partners, a multitude of sampling strategies was employed within a circular research methodology based on constructivist Grounded Theory (Charmaz, 2006). First, the findings of the previous phases of the project-an interpretative policy analysis and a discourse analysis-informed our theoretical sensitivity (Glaser, 1978) as well as the theoretical sampling itself (Strauss, 1987). We aimed at keeping our sample as heterogeneous as possible in terms of employment status (regular/irregular, temporary/permanent), education level, age, gender, and family status. Yet, theoretical sampling was fuelled across the country pairs through regular discussions of ongoing analytical work, especially regarding the coding work done within the country-pair teams. When recruiting interview partners, we also relied on snowball-strategies, but first approached individuals through a series of channels such as migrant organisations, social networks, internet platforms, and acquaintances. We first interviewed random individuals from the 'new' member states who were investigated with a very general interview guideline in order to see when and how they addressed the topic of (transnational) social security. Subsequently, we focused solely on migrants with portability experiences who were of working age and stayed at least five nights in a certain city of the 'old' member state. The length of the interviews ranged from 45 minutes to three hours. More than three-quarters of the interviews were carried out in the migrants' first language by the junior researchers of this project. Team formation was actually done, inter alia, because of researchers being native speakers in at least one of the four sending countries' languages. While the country team-specific fieldwork and analyses were carried out by the respective country teams, the Austrian-Hungarian team (lead: Elisabeth Scheibelhofer) was responsible for establishing common methodological grounds as well as the comparative analysis. However, in contrast to usual practices in international research collaborations of this kind, the comparative work did not only commence after the country pairs provided their internal reports but was an integral part of a continuous and highly communicative (also online) research process (Scheibelhofer, Holzinger \& Regös, in press). The exchange on significant (preliminary) findings during empirical fieldwork led to intensive discussions across and within the national research teams and fuelled further theoretical sampling as well as the understanding and the perception of the qualitative work partly presented below.

Following a Grounded Theory approach, the comparative work allowed to gain a better understanding of the experiences as well as the meaning-making processes involved when accessing (transnational) social security rights without applying pre-formed or pre-theoretically developed categories. It served to reconstruct patterns in the experiences that we had not expected to find initially (e.g., the importance of transnational health care in the UK), but which emerged from the empirical data and were related to the relevant literature in a final step of the analysis. It became apparent that despite the differences in welfare systems, divergent political debates, and cultural norms, migrants had in certain instances astonishingly similar experiences across our four bi-national case studies. Yet, the differences comparing the four country pairs are also part of the analyses car- 
ried out and presented elsewhere (Scheibelhofer et al., in press). In the following, we will elaborate on how mobile EU citizens cope with two major obstacles they face when trying to access their social rights (transnationally). As we will show, complex and incompatible welfare regulations, as well as exclusion based on transnational lifestyles, lead to experiences of discrimination.

\section{Dealing with Complex and Transnationally Incompatible Regulations: Creative Welfare Learning as a Necessity}

Gaining relevant insights and knowledge proved to be the dominant recurrent issue in all interviews. We concur with previous research on EU migrant citizens and welfare state access in that people usually arrive with little to no knowledge about the given countries' welfare systems (Ehata \& Seeleib-Kaiser, 2017). Policy analyses of the European and national regulations on access to and the portability of social security rights have shown that access is highly conditional and depends on the mobile EU citizens' form of mobility and labour force status (Carmel, Sojka, \& Papiez, 2016). Through qualitative interviews, we collected numerous narratives that demonstrated how tedious it is to make one's way through the labyrinths of transnational social security (Scheibelhofer et al., in press), even for those migrants who spent considerable time and effort acquiring adequate information. However, language issues and difficulty in acquiring information are not the only aspects preventing migrants from sufficiently understanding regulations.

In the course of our fieldwork, we regularly came across migrants experiencing that the welfare institutions of the two EU countries involved had difficulties providing accurate information needed to further process their applications. For the interviewees this resulted in considerable paperwork and travelling (also internationally) to different institutions. While some migrants decided to waive their rights when faced with substantial difficulties, others persevered. The latter however often reported losing at least a part of their social benefits due to incompatible national regulations. Although EU regulations provide that EU citizens should not lose welfare rights in the case that they are mobile, our findings indicate that in practice, and in many instances, national welfare regulations and administrative procedures at different scales within the EU are found to be incompatible. The interviewed migrants expressed feelings of being left alone with the regulatory complexities and transnational inconsistencies (Heindlmaier \& Blauberger, 2017). Our interview partners also claimed to be misinformed by institutions and sometimes questioned the officials' expertise concerning intricate EU regulations and their transpositions into national policies (Blauberger \& Schmidt, 2014). While further research is needed regarding the positions of street-level bureaucrats-as Lipsky (1980) named front-line workers in public services-in the highly complex decision-making processes (some lit- erature hints at the changing work conditions, e.g., Penz, Sauer, Gaitsch, Hofbauer, \& Glinsner, 2017), we established that legally false information greatly impacted the interviewees' access to social benefits.

Lidia, a 29-year-old woman wanting to pursue her university education while working in Germany, was discouraged at her Bulgarian labour office to transfer her unemployment benefits to Germany. As Lidia understood, the official claimed that drawing Bulgarian unemployment benefits when residing in Germany would be illegal. However, this information is legally wrong. While the recipients of unemployment benefit are usually to stay in the last country of employment, EU regulations allow for the possibility to export unemployment benefits under certain circumstances, i.e., to seek work in another EU country while receiving unemployment benefits for up to six months from the country where one became unemployed (European Council [EC 883/2004], 2004, article 64). Although our interview partner did not fully trust this (indeed legally false) information that she had received from the official, she did not pursue her doubts any further and thus could not realise her right to export unemployment benefits. While Lidia decided to let go, we found other examples of migrants in all four countrypairs who learned to deal with administrations and over time became skilled in accessing their (transnational) social rights. In our interpretive analysis, we thus coined the expression of 'welfare learning' in order to describe the different narratives of how information is gathered after arrival. However, learning the ropes of the systems sometimes also proved to happen too late. An exemplary case was Natalja, an Estonian senior consultant in the finance sector who worked and became unemployed in Sweden. In order to be eligible for earning-based unemployment benefits, employees in Sweden need to register separately for a union membership for at least one year. This may be a problem, especially for migrants who come from a system in which unemployment insurance is provided automatically with employment, which they would initially assume would work similarly in Sweden. This was the case for Natalja who found out about this necessary requirement too late:

At once, I went to Arbetsförmedlingen for information regarding unemployment benefits....When I moved, no one at my first job told me that you have to register separately at Arbetsförmedlingen, A-kassa, to pay, etc. I'll become eligible in June and I know that if I lose my job, then they'll pay me at least $80 \%$ of my salary. The time I just moved here, no one told me about that, and I was left 'high and dry' when I lost my job. I've learned through my own bitter experience.

Not knowing the national regulations, Natalja was unable to receive the income-based unemployment benefit when she lost her job the first time. It was only after this 'bitter experience' of being excluded from social rights that she immediately signed up for unemploy- 
ment insurance once she took up another position. Yet moving from a post-communist welfare state to a welfare system that can be classified as liberal, social democratic or conservative corporatist, though we agree with Carmel and Papadopoulos (2016) that these categorisations only partially reflect the diversities among welfare states, it can also be accompanied by positive learning experiences. For instance, some interview partners discovered social benefits in their migration country which do not exist (at least at the same level) in their countries of origin. For instance, Cezary, a 35-year-old subcontract worker living with his family in UK, extolled the welcomed surprise of straightforward access to cheaper or even gratuitous medication for people with low income or chronic diseases:

There is a great thing in England, which I like. This does not exist in Poland. It is a white card from NHS [National Health Service]. Actually if you have one benefit, then you could have more benefits. If you have one, then you have them all.

As such, learning the ropes of the system was also a positive experience. However, it proved not to suffice in some situations migrants had to handle (transnationally) in order to access social security. They found themselves forced to come up with their own highly creative solutions to barriers that seemed insurmountable. Réka, a 29-year-old university graduate from Hungary, provided an example of how to creatively deal with institutions in such transnational settings. At the time of the interview, she was working in a media company in Vienna. She told us about the difficulties she had encountered in detail, acting according to the regulations in Hungary and Austria during the period of her relocating to Austria. Hungarian administration demands to be notified within 15 days if health insurance is established abroad and the Hungarian insurance has to be cancelled within the same period. In practice, however, this proved to be very difficult, as none of the three involved authorities (which always pointed to one another in terms of final competence) would accept her cancellation form. Thus, Réka came up with a creative solution:

So, they were directing me back and forth. Nobody wanted to assume the responsibility that it was part of his or her competences....I decided that I was not going to waste my time any longer since I already had the form that I had to fill out. So, I sent it attached with an explanation letter that I wanted to renounce my health insurance. I basically asked the authorities to communicate amongst each other because I had sent this form to all of them, so they knew that it was everything I could have done [laughs].

Réka used her social networks, including befriended lawyers she consulted, and discovered an EU form (E106) intended for frontier workers to certify their entitlement to health care services in the country of residence. She came up with the idea to use this form for her own ends (as described above in her own words), which proved to be a highly sophisticated and successful strategy.

While Réka tried to exit a specific welfare institution, Tiit, a 47-year-old truck driver from Estonia, faced a powerful threshold when attempting to enter the Swedish welfare system. In Sweden, a permanent personal identification number (PIN) is required when accessing most social benefits. Yet, PINs are only issued in case applicants can provide evidence of permanent work and housing. As receiving an apartment lease depends on holding a work contract and vice versa, migrants usually have to come up with creative strategies to receive PINs - with one exception, i.e., if they are already hired by a Swedish firm prior to their arrival in Sweden. Tiit, being aware of this tricky situation, asked fellow workers and found out that by being self-employed, he could procure the necessary work documentation in order to successfully apply for a PIN. Thus, he proceeded with his endeavour:

I had this clever idea. I went to the office; I do not remember which office it was where they also register enterprises. Something related to migration. I went there and said that I am a foreigner and want to start my own company. I do not want to work here....but I did not get further from there, one person told me one thing, another a totally different thing, I do not remember anymore.

While Tiit was not successful with his creative coping strategy, another interview partner disclosed that his father who, still living in Estonia, was able to set up his own company in Sweden and consequently received the Swedish PIN. We could observe in our empirical data that such coping strategies are shared by means of diverse channels-be it through circles of co-ethnics, off- and online, through the help of co-workers and new acquaintances, or through NGOs and (paid-for) lawyers. Generally, social networks constitute an important source of information and also prove to be important regarding informal help that is provided (transnationally) from family, friends, acquaintances, and colleagues on a day-to-day basis. Especially co-ethnic help through websites and associations turned out to be relevant in terms of 'learning the ropes' of the welfare system. Comparing the country pairs, this was least evident in Sweden-which might be due to the comparatively small Estonian diasporic community with a rather brief migratory history in this country.

The aim of this section was to illustrate the difficulties for individual migrants emanating from what they perceive as complex and often incompatible transnational welfare regulations. During coding, we created the term of welfare learning in order to describe that migrants do not only have to learn the ropes of the new welfare system (often by themselves) but also need to acquire and employ (creative) coping strategies to gain access to (transnational) social rights. 


\section{Transnational Lifestyles Colliding with National Container Policies}

The European project has been referred to as a peace project. It has also been perceived as the best-practice laboratory of current post-national welfare states' futures, relying on the principle of non-discrimination by nationality (Favell, 2016). Mobile Europeans have been discussed as those who promote the European project in terms of establishing Europeanness (Recchi, 2015).

Over the past decades, transnationally oriented migration research has established that migration is rarely a one-time, one-way process, as had previously been assumed. The ways in which these conceptions are based on a social scientific understanding per se of nationstates has been broadly debated since the early 2000s (Amelina, Nergiz, Faist, \& Glick Schiller, 2012; Scheibelhofer, 2010; Wimmer \& Glick Schiller, 2002). However, while debates around methodological nationalism have arrived at the core of migration scholarship (although we are by no means 'done' with the issues raised), EU regulations and national as well as regional laws still fail to sufficiently take the varieties of transnational lifestyles into account. This has far-reaching consequences that came to the fore while doing interviews with EU mobile citizens. Having family members in a 'new' EU member state and travelling back and forth on a regular basis was not uncommon in our sample. One might assume that such citizens are those 'true Europeans' the EU could build upon for its future in order to overcome the particularistic interests of its member states. Yet, far from that, our empirical work rather suggests that current regulations, based on the definition of one competent member state, are problematic in the context of economic asymmetries between the countries as they disadvantage certain types of commuters. As we observed, national welfare institutions in the economically better-positioned receiving countries often acted according to what may be described as national interests. They functioned as rather severe gatekeepers and prevented migrants from accessing social benefits by rejecting the competence for their case. In all four investigated country-pairs, we met migrants who reported difficulties that resulted from the necessity to define one member state which is competent for the provision of welfare benefits. This mostly occurred by identifying one 'centre of interests' (meaning the country where a person has the closest personal and/or economic relationships) echoed by various national residency tests that were introduced in the four receiving countries studied (Carmel et al., 2016; Regös, Holzinger, \& Scheibelhofer, in press; Scheibelhofer et al., in press). In the following, we will focus on several ideal-typical instances that illustrate the tensions between the transnational lifestyles adopted by EU migrants and policies targeting national closure in terms of welfare access. As already stated, we found such cases in all four country-pairs, yet their importance was most obvious in the Austria-Hungary country- pair that we came to characterise, also in terms of everyday life realities, as a greater border region (Regös et al., in press). As travelling back and forth is part of everyday life practices and very common in this region, many interview partners experienced difficulties, especially when accessing unemployment benefits because they were often categorised as 'frontier workers' by the Austrian Public Employment Service (AMS). According to the European Regulation EC 883/2004 (European Council, 2004), article 1(f), a frontier worker is an individual working in a member state and who resides in another member state to which he or she returns at least once a week. The determination of residence is based on the establishment of the 'centre of interests' of the person concerned which in turn is defined by inter alia having one's family members in such a place, the main housing facility, business interests and/or leisure time activities (European Council [EC 987/2009], 2009, article 11). While the country of employment is generally responsible for the payment of unemployment benefit, it is the country of residence (where the 'centre of interests' is located by authorities) in the case of frontier workers. For our interview partners, being categorised as a 'frontier worker' entailed falling under the jurisdiction of Hungary and consequently losing entitlement to the Austrian unemployment benefit, which is nearly four times higher (own calculations based on OECD, 2010) than its Hungarian counterpart (see also Regös et al., in press). As we observed during our fieldwork between May 2015 and October 2017, Hungarians found their cases under increasing scrutiny when applying for unemployment benefit and had to defend themselves from the general suspicion of having their 'centre of interests' in Hungary (thus being 'frontier workers' in Austria). Most notably, a standardised form to prove the competency of the AMS was introduced. It is described in detail in the following narration of Szabolcs, a 27-year-old Hungarian university graduate who shared the following experience with the local AMS office in Vienna:

They gave me a document about how often I travel to Hungary, whether I have a Hungarian car, ahm, how many days I spend here, whether I have an apartment in Hungary, who of my relatives live in Hungary, and I, in this situation, I felt that nobody ever asked me these questions. And this was the first moment when I felt that, damn it, I am a miserable Eastern European in the eyes of the administrator.

Although not mentioned explicitly in the form, the contained questions are in line with the criteria mentioned in the European social security coordination regulations (European Council [EC 987/2009], 2009, article 11; see also Carmel et al., 2016) in order to identify the 'centre of interests' - and thus the competent member state to procure welfare services. The introduction of this questionnaire was not announced on websites or otherwise and thus resulted in a feeling of arbitrariness and per- 
ceived discrimination. It was not the first time that Szabolcs applied for unemployment benefits, but this time, he understood that he was confronted with the aforementioned questionnaire only because of his Hungarian nationality. In the above passage, he thus expressed his feeling of being discriminated against (an aspect discussed in detail below) and labelled as a "miserable Eastern European" in this situation with an official.

The problems attached to defining the competent member state by establishing one's 'centre of interests' are manifold. EU citizens are interrogated and feel they are put to the test if they rightfully claim their interests as foreigners, as others. Moreover, transnational lifestyles are by now common and many interview partners indeed travel regularly to their countries of origin. Migrants may have apartments or places where they live in two EU member states or they may have close family members whom they try to see as often as their jobs in the 'old' member states permit. Thus, the very concept of having 'one centre of interests' only is problematic as not all indicators constructed by authorities and political decisionmakers may point to a single location in one member state only. This is especially true for individuals involved in transnational family arrangements. In our sample, we had such cases, one of them being Raivo, a 47-year-old Estonian migrant. He was employed as a construction worker in Sweden while his wife and two teenage children were living in Estonia. Applying for a PIN, he encountered difficulties with the Swedish administration due to his transnational living conditions:

They had a problem there that my family is in Estonia, children are in Estonia. One child was younger than 18 by then. And that was it. And then they started telling me in connection with the marriage that, Jesus Christ, how can it be that your wife is there and you are here.

Transnational family arrangements are part of today's world, as has been widely shown in migration research (Baldassar \& Merla, 2014; Bryceson, 2002). While regionally separated household compositions are not constructed as socially problematic (e.g., in terms of commuting on a daily or weekly basis within one nationstate), crossing borders when doing so becomes an issue once an individual falls sick or is unemployed. In these instances, equal treatment within the EU ends at those EU internal borders that are said to become less important. Also, labour market structures and common economic practices in specific sectors contribute to problems of exclusion based on transnational lifestyles. In Austria for example, it is common that construction workers (a sector with high employment rates of Hungarians) are laid off in winter during low season and receive unemployment benefits for the months in question. For native Austrians whose families reside in another Austrian region, this practice does not lead to any problematisation of benefit reception. Yet if Hungarians travel the same amount of time and kilometres to be with their families, thereby crossing national borders, this results in a loss of the greater part of their unemployment benefits because recipients of the Austrian unemployment benefit see their payments suspended while staying abroad. This again reflects an instance of discrimination that transnational mobile Europeans face accessing social securitywhich in turn highlights the tension between a great variety of transnational lifestyles and national policies.

As we intended to show in this section, our interviewees experienced mechanisms of exclusion within welfare regulations that are rooted in sedentary normative assumptions and a container-like conceptualisation of who should be covered by national social security. Along with the feeling of being left alone with complex and seemingly incompatible welfare regulations (covered in the previous section), these tensions between transnational lifestyles and national policies lead to experiences of discriminations for mobile EU citizens which we will address in the following section.

\section{Experiencing and Coping with Discrimination}

Szabolcs's experiences and his understanding of those experiences were already touched upon above. Being ascribed what he sensed as the demeaning status of an 'Eastern European' was "humiliating" for him, as he explicitly stated. We analytically defined discrimination in two ways. Either interviewees would personally perceive themselves as discriminated against-as exemplified in Szabolcs's case-or we as researchers would interpret interactions, omissions or narrations as instances of discrimination (Verwiebe, Seewann, Wolf, \& Hacioglu, 2016; Weiß, 2002). Applying for unemployment benefits or for a PIN proved to be pivotal points of decision-making in which migrants faced discriminatory practices and/or perceived their treatment as discriminatory. In the case of Raivo, living in a transnational family was an obstacle when applying for a Swedish PIN. Going through the application process, Raivo understood that his contribution to the Swedish state was not appreciated, in turn leading him to compare his performance as a contributing citizen to other groups of 'newcomers'. Raivo reflected upon the reasons for being denied a PIN:

I have no idea what they were thinking and why they did so. I was angered by this. If there would have been an institution to write to....All kinds of people come to Sweden and get all their documents immediately. They do not even work, they only live off state support. They get apartments, they get allowance to support themselves. Whatever. We [Estonians] have been slaves to the Swedish state, in a direct sense built up the state and I was not asking for much.

Experiences of discrimination are linked to selfidentification with an ethnic group, such as Estonians in the case of Raivo. In the other country-pairs, we also encountered migrants in whose narrations we identi- 
fied similar combinations of experiencing discrimination when trying to access social welfare and boundarymaking of an ethnic/national group (Wimmer, 2007). Cezary, whose case we alluded to above, had received the advice of co-ethnics not to speak Polish at the job centre, as doing so would possibly cause immediate rejection of his claim. He also suggested that based on the 'Polishness' of given individuals, officials would provide different services than to 'natives': "Polish people are treated worse. When I was at the job centre, friends told me that I should be quiet and not speak Polish, because we would not receive benefits if they hear that we are Polish".

How, and if at all, the migrants chose to deal with welfare institutions greatly depended on their take on social benefits and the role of the state attributed in this respect. In all four country-pairs, we mainly met migrants who presented themselves as hard-working individuals whose goal was to maintain themselves as well as they could in a self-sustaining way and to contribute to society. We created the code of 'the good migrant' in order to capture this moment. In our analyses, this code served to refer to the persisting incidents in the interviews in which the migrants presented themselves as gainful and law-abiding, and not requesting social benefits. Repeatedly, the interview partners across the four country-pairs stressed their difference by bringing up other ethnicised groups, such as 'the gypsies' in the German-Bulgarian context or 'the refugees' in the Austrian as well as the Swedish part of the study. We concur with Cederberg (2014) that migrant self-positioning is to be analysed in the light of the ongoing public discourses as they might be closely interrelated. Based on our fieldwork, we add that the image of 'the good migrant' may thus also be connected to experiences of discrimination.

This reasoning brings us back to the arguments made at the beginning of this article. Confusing and unclear regulations play a major role in mobile EU citizens' actual limitations of access to social benefits. This complexity, as well as the tensions emanating from the contradictions between European regulations, national policies, and transnational lifestyles, leads to experiences of discrimination and perceived 'otherness'. For the sake of clarity, the above analysis was divided into three sections focusing on one of these aspects. In practice, however, we see that these instances are often interlinked with one another when it comes to the question of accessing social security as an EU migrant.

\section{Conclusions}

While the EU has certainly established globally unique regulations as to governing social security for its citizens within the EU territory, individuals' experiences with accessing (transnational) social security showed a more nuanced picture. In the four country-pairs, the migrants' experiences and interpretations thereof astonishingly converged at many critical points of their narratives. The difficulty to procure adequate information and to navigate successfully through the labyrinths of social security systems recurred in most of the 81 interviews after the individuals had tried to access social security in the areas of family benefits, unemployment, pension, or health. In addition, we found that experiences of discrimination were common for the interview partners and that those who were involved in transnational migration often found themselves excluded from social benefits once they were in need of social protection. Based on our results, and due to various circumstances discussed above, we conclude that mobile EU nationals have lower chances of being treated as equals if they attempt to access social security in a given EU member state. More precisely, our results also show the extent of unequal access for citizens from the 'new' member states who move to the so-called 'old' member states. We can thus clearly see a momentum of colliding political interests working on different scales. While EU regulations tend to protect EU citizens from discrimination-attempting to ensure their inclusion also in terms of social security when being mobile-we see that the national and regional transpositions of these EU regulations (and court rulings) into national frameworks tend to exclude EU mobile citizens. One major obstacle for intra-EU migrants when navigating the labyrinths of transnational social security is its high complexity and the difficulties of welfare learning together with an emphasis on individual responsibility which must be seen embedded in the new European social project which endorses the active participation of citizens (Soysal, 2012). In her contribution, Soysal explains how such entanglement ultimately leads to and reinforces social stratification within the EU. As we have seen in our research, member states increasingly put in place administrative barriers that are based on EU regulations. The latter ones were initially meant to assist the inter-state decision-making of welfare institutions in establishing which member state would be responsible for delivering social services (Carmel et al., 2016). Social exclusion is clearly administered differently in the four EU receiving countries in our study (e.g., via the PIN system in Sweden), as welfare systems and the histories thereof differ. Nevertheless, through our Grounded Theory study we reconstructed experiences of social exclusion among EU citizens from the 'new' member states in all four country-pairs that shared some characteristics in peculiar ways as described above. What transnational regulations at all discussed scales have in common is that they put one single centre of interests as given. This is the point of reference that creates social exclusion for those who live in transnational family constellations or who constantly commute between two member states. Living and working during the week in an 'old' EU member state does not necessarily suffice to construct one's own centre of interests in that very place. Social commitments, such as being an active member in an association or having one's immediate family members in the same nation-state, were crucial to the EU migrants we 
interviewed in terms of access to social benefits. Thus, there is a clandestine gap between the political rhetoric of a united Europe without inner borders, based on free movement and the equality of all its citizens, and those who act upon these premises and move to another EU member state.

\section{Acknowledgments}

The three-year research project TRANSWEL (2015-2018) was funded by NORFACE via FWF collaboration (FWF Project Number I 2025-G16). We wish to thank our international colleagues from the TRANSWEL team for their contribution to this project. In particular, we want to express our appreciation to Nora Regös for her valuable work in the empirical fieldwork and the comparative analysis (the title of this article is a quotation extracted from an interview conducted by her in 2016).

\section{Conflict of Interests}

The authors declare no conflict of interests.

\section{References}

Amelina, A., Nergiz, D. D., Faist, T., \& Glick Schiller, N. (2012). Beyond methodological nationalism. Research methodologies for cross-border studies. New York, NY: Routledge.

Avato, J., Koettl, J., \& Sabates-Wheeler, R. (2010). Social security regimes, global estimates, and good practices: The status of social protection for international migrants. World Development, 38(4), 455-466.

Baldassar, L., \& Merla, L. (Eds.). (2014). Transnational families, migration and the circulation of care: Understanding mobility and absence in family life. New York, NY: Routledge.

Blauberger, M., \& Schmidt, S. K. (2014). Welfare migration? Free movement of EU citizens and access to social benefits. Research \& Politics, 1(3), 1-7.

Bryceson, D. (2002). Europe's transnational families and migration: Past and present. In D. Bryceson \& U. Vuorela (Eds.), The transnational family: New European frontiers and global Networks (pp. 31-63). Oxford: Berg.

Carmel, E., Cerami, A., \& Papadopoulos, T. (2011). Migration and welfare in the new Europe: Social protection and the challenges of integration. Bristol: The Policy Press.

Carmel, E., \& Papadopoulos, T. (2016). Detached, hostile, adaptable and liberalising: The chameleon qualities of the UK's relationship with EU social policy. The Political Quarterly, 87(2), 228-237.

Carmel, E., Sojka, B., \& Papiez, K. (2016). Free to move, right to work, entitled to claim? Governing social security portability for mobile Europeans (WSF Working Paper Series). Retrieved from www.welfarestatefutures.files.wordpress.com
Cederberg, M. (2014). Public discourses and migrant stories of integration and inequality: Language and power in biographical narratives. Sociology, 48(1), 133-149.

Charmaz, K. (2006). Constructing Grounded Theory: A practical guide through qualitative analysis. Thousand Oaks, CA: Sage.

Dobbs, E., \& Levitt, P. (2017). The missing link? The role of sub-national governance in transnational social protections. Oxford Development Studies, 45(1), 47-63.

European Council. (2004). Regulation of the European parliament and of the council of 29 April 2004 on the coordination of social security systems EC $883 / 2004$. Retrieved from eur-lex.europa.eu/search. html ?qid $=1529935006872 \&$ text $=883 / 2004 \&$ scope $=$ EURLEX\&type=quick\&lang=en

European Council. (2009). Regulation of the European parliament and of the council of 16 September 2009 laying down the procedure for implementing Regulation (EC) No 883/2004 on the coordination of social security systems EC 987/2009. Retrieved from eur-lex. europa.eu/search.html?qid=1529935075723\&text= 987/2009\&scope=EURLEX\&type=quick\&lang=en

Ehata, R., \& Seeleib-Kaiser, M. (2017). Benefit tourism and EU migrant citizens: Real-world experiences. In J. Hudson, C. Needham, \& E. Heins (Eds.), Social policy review 29: Analysis and debate in social policy 2017 (pp. 181-198). Bristol: Policy Press.

Faist, T. (2017). Transnational social protection in Europe: A social inequality perspective. Oxford Development Studies, 45(1), 20-32.

Faist, T., Bilecen, B., Barglowski, K., \& Sienkiewicz, J. J. (2015). Transnational social protection: Migrants' strategies and patterns of inequalities. Population, Space and Place, 21(3), 193-202.

Favell, A. (2016). Liberalism, not Neo-Liberalism. Comment on Will Kymlicka's article: "Solidarity in Diverse Societies". Comparative Migration Studies, 4(1), 5.

Glaser, B. (1978). Theoretical sensitivity: Advances in the methodology of grounded theory. Mill Valley, CA: Sociology Press.

Heindlmaier, A., \& Blauberger, M. (2017). Enter at your own risk: Free movement of EU citizens in practice. West European Politics, 40(6), 1198-1217.

Kymlicka, W. (2015). Solidarity in diverse societies: Beyond neoliberal multiculturalism and welfare chauvinism. Comparative Migration Studies, 3(1), 17.

Levitt, P., Viterna, J., Mueller, A., \& Lloyd, C. (2017). Transnational social protection: Setting the agenda. Oxford Development Studies, 45(1), 2-19.

Lipsky, M. (1980). Street-level bureaucracy. New York, NY: Sage Publications Ltd.

OECD. (2010). Detailed description of part-time work regulations and unemployment benefit schemes affecting part-time workers. Supporting material for chapter 4 "How good is part-time work?" of the 2010 OECD Employment Outlook. Paris: OECD. Retrieved 
from www.oecd.org/els/emp/45565142.pdf

Penz, O., Sauer, B., Gaitsch, M., Hofbauer, J., \& Glinsner, B. (2017). Post-bureaucratic encounters: Affective labour in public employment services. Critical Social Policy, 37(4), 540-561.

Recchi, E. (2015). Mobile Europe: The theory and practice of free movement in the EU. Basingstoke: Palgrave Macmillan.

Regös, N., Holzinger, C., \& Scheibelhofer, E. (in press). When vicinity divides: Transnational social security in the cross-border region of Hungary and Austria. In A. Amelina, E. Carmel, A. Runfors, \& E. Scheibelhofer (Eds.), Boundaries of European citizenship: Regulations, discourses and experiences of transnational social security. New York, NY: Routledge.

Sabates-Wheeler, R., \& Koettl, J. (2010). Social protection for migrants: The challenges of delivery in the context of changing migration flows. International Social Security Review, 63(3/4), 115-144.

Sabates-Wheeler, R., Koettl, J., \& Avato, J. (2011). Social security for migrants: A global overview of portability arrangements. Rethinking International Development Series, 91-116. https://doi.org/10.1057/ 9780230306554_4

Scheibelhofer, E. (2008). Combining narration-based interviews with topical interviews: Methodological reflections on research practices. International Journal of Social Research Methodology, 11(5), 403-416.

Scheibelhofer, E. (2010). Space-sensible sociology of migration. How migration research can profit of sociospatial theories (Working Paper 77/2010, COMCADCenter on Migration, Citizenship and Development). University of Bielefeld, Bielefeld.

Scheibelhofer, E., Holzinger, C., \& Regös, N. (in press).
Navigating the labyrinths of transnational social security: Experiences and meaning-making processes of EU migrants when accessing and porting social benefits. In A. Amelina, E. Carmel, A. Runfors, \& E. Scheibelhofer (Eds.), Boundaries of European citizenship: Regulations, discourses and experiences of transnational social security. New York, NY: Routledge.

Soysal, Y. (2012). Citizenship, immigration, and the European social project: Rights and obligations of individuality. The British Journal of Sociology, 63(1), 1-21.

Strauss, A. (1987). Qualitative analysis for social scientists. Cambridge: Cambridge University Press.

Verwiebe, R., Seewann, L., Wolf, M., \& Hacioglu, M. (2016). 'I have to be very good in what I do': Marginalisation and discrimination in the career-entry phase. Experiences and coping strategies among university graduates with a migrant background in Austria. Journal of Ethnic and Migration Studies, 42(15), 2468-2490.

Weiß, A. (2002). Raumrelationen als zentraler Aspekt weltweiter Ungleichheiten. Mittelweg 36, 4(25), $1-16$.

Wimmer, A. (2007). How (not) to think about ethnicity in immigrant societies. Toward a boundary-making perspective (ESRC Working Papers Series, WP no. 44). Retrieved from www.compas.ox.ac.uk/2007/wp-2007044-wimmer_ethnicity_immigrant_socities

Wimmer, A., \& Glick Schiller, N. (2002). Methodological nationalism and beyond: Nation-state building, migration and the social sciences. Global Networks, 2(4), 301-334.

Witzel, A., \& Reiter, H. (2012). The Problem-Centered Interview. London: Sage Publications Ltd.

\section{About the Authors}

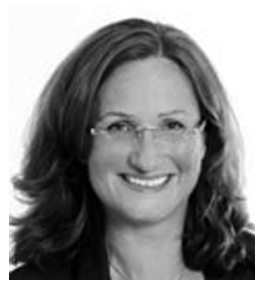

Elisabeth Scheibelhofer is an Associate Professor of Sociology (University of Vienna) working on migration, mobility, and qualitative methods. She is currently leading the Hungarian-Austrian part of the TRANSWEL research project (2015-2018), funded by Norface, on experiences of EU migrants with transnational access to social security rights. She has published extensively on migration and qualitative methods, as in her article "Shifting aspirations in migratory projects" (Journal of Ethnic and Migration Studies, 44(6), 999-1014).

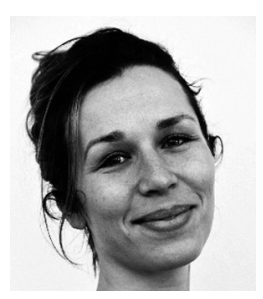

Clara Holzinger works as a Research Assistant and Lecturer at the Department for Sociology, University of Vienna, Austria. She is a member of the Hungarian-Austrian part of the TRANSWEL research project (2015-2018), funded by Norface. She has a disciplinary background in Sociology, Applied Linguistics, and History. Her research interests focus on qualitative empirical methods, migration, welfare, multilingualism, and language policy. 